\title{
Effects of Drying Condition and Binding Agent on the Quality Characteristics of Ground Dried-Pork Meat Products
}

\author{
Yun-Sang Choi, Su-Kyung Ku, Jong-Dae Park, Hee-Ju Kim, Aera Jang², and Young-Boong Kim* \\ Food Processing Research Center, Korea Food Research Institute, Sungnam 13539, Korea \\ ${ }^{1}$ Meat bank, Inchon 22650, Korea \\ ${ }^{2}$ Department of Animal Products and Food Science, Kangwon National University, Chuncheon 24341, Korea
}

\begin{abstract}
The purpose of this study was to investigate the influence of processing conditions (temperature and time) and binding agent types (glutinous rice flour, potato starch, bean flour, and acorn flour) on the physicochemical and sensory characteristics of ground dried-pork meat product. For this purpose, ground dried-pork meat product was produced by adding several binding agents at different drying temperatures and times. The drying time affected moisture content and water activity in all drying temperature. However, under the similar drying conditions, the extent of drying varied depending on the type of binding agents. The results of sensory evaluation for texture degree and overall acceptability indicated the following: overall, higher drying temperatures and longer drying time heightened the degree of texture, and the overall acceptability varied depending on binding agent type. Physicochemical and sensory characteristics were analyzed to determine any possible correlation. The results revealed a high correlation between moisture content, water activity, shear forces, and sensory evaluation $(p<0.01)$. However, there was no correlation with respect to overall acceptability.
\end{abstract}

Key words: Dried meat, water activity, binding agent, drying condition, sensory properties

\section{Introduction}

The ratio of dining out in our lives has increased drastically due to diversified and simplified food consumption styles in Korea. Accordingly, the demand for various meat processing productions has also increased from grilling of livestock products (Lee and Jin, 2004; Park and Lee, 2005). Jerky is the most commonly available dried meat product, which is sliced, seasoned and dried with rich protein and low lipid contents in various types and shapes (Lee and Park, 2004). Beef, lamb, pork, chicken and venison are also most commonly used to prepare various meat products (Carr et al., 1997; Choi and An, 1996; Lee and Kang, 2001; Munoz et al., 2012; Park et al., 2009; Pegg et al., 2006; Van Laak, 1994). Dried meat is named differently like, jerky in North America, pemmican in the Arctic Circle, carne-de-sol and charqui in Brazil, biltong in South Africa, and koppa, speck or

*Corresponding author: Young Boong Kim, Food Processing Research Center, Korea Food Research Institute, Sungnam 13539, Korea. Tel: +82-31-780-9180, Fax: +82-31-780-9076, E-mail: kybaaa@kfri.re.kr pastirma in Europe (Biscola et al., 2013; Lee and Park, 2004; Leistner, 1987; Thomas et al, 2014).

Drying method increases the storage period of meat and meat products, it reduces moisture content and water activity $\left(\mathrm{a}_{\mathrm{w}}\right)$ in order to prohibit microbial growth (Chang et al., 1996; Dzimba et al., 2007; Rahman et al., 2005). A high correlation between $\mathrm{a}_{\mathrm{w}}$ and moisture content has been reported (Allen et al., 2007), and also there are reports that suggest lowering of $\mathrm{a}_{\mathrm{w}}$ by addition of salt and sugar (Banwart, 1979; Han et al., 2007; Lee et al., 1997; Mgbemere et al., 2011). Moisture content of general jerky is about $30 \%$ and $\mathrm{a}_{\mathrm{w}}$ ranges between 0.70 and 0.75 , which is the intermediate moisture food (IMF) value; this process renders storage of jerky for more than 6 mon (Torres et al., 1994). The scope of $\mathrm{a}_{\mathrm{w}}$ for microbial growth varies by various types of microbial. Most of the halotolerant bacteria can grow at $\mathrm{a}_{\mathrm{w}}$ of $0.80-0.85$, whereas a small number of halotolerant bacteria can grow at 0.75 (Bone, 1973; Labuza et al., 1972). Growth of mold ranges between $\mathrm{a}_{\mathrm{w}}$ of 0.80 and 1.00 , and that of yeast between 0.88 and 1.00. However, it has been reported that some xerophilic molds and osmophilic yeasts can grow at a low $\mathrm{a}_{\mathrm{w}}$ of 0.65 and 0.60 , respectively. For manufacturing meat

(9)This is an open access article distributed under the terms of the Creative Commons Attribution Non-Commercial License (http://creativecommons.org/licences/ by-nc/3.0) which permits unrestricted non-commercial use, distribution, and reproduction in any medium, provided the original wokr is properly cited. 
products, it has been reported that carbohydrate (as nonmeat ingredient) could play a role in increasing emulsification stability, yield, and texture and decreasing oilwater separation by prohibiting contraction of network structure in meat proteins (Allais, 2010). However, research on ground dried-pork meat product prepared with combination of processing conditions and binding agent types is limited.

Therefore, the objective of this study was to investigate the effects of processing conditions (temperature and time) and binding agent types (glutinous rice flour, potato starch, bean flour, and acorn flour) on the quality characteristics of ground dried-pork meat product.

\section{Materials and Methods}

\section{Materials and treatment}

Fresh pork ham (castrated boars; Landrace $\times$ Yorkshire $\times$ Duroc; approximately $110 \mathrm{~kg}, M$. biceps femoris, $M$. semitendinosus, M. semimembranosus, moisture about $70 \%$, protein $18 \%$, fat $10 \%$ and ash $1 \%$ ) was purchased from a local processor $48 \mathrm{~h}$ postmortem. All subcutaneous, intramuscular fat and visible connective tissue were removed from muscle. Lean materials and the pork fat were initially ground through an $8-\mathrm{mm}$ plate. The ground tissue was then placed in polyethylene bags, vacuum sealed using a vacuum packaging system (FJ-500XL, Fujee Tech, Korea) and stored at $0^{\circ} \mathrm{C}$ until required for product manufacturing. Mixing ratio for ground dried meat consists of raw meat of $76.75 \%$, binding agent (glutinous rice flour, potato starch, soybean flour and acorn flour) of $9 \%$, purified water of $9.97 \%$, carrageenan of $1 \%$ and other additives such as curing ingredients of $3.31 \%$, totaling $100 \%$. For manufacturing, mixed with raw meat and ingredient materials for $20 \mathrm{~min}$ by using vacuum mixer (Mixer-600, Hyupjin Co., Korea). The mixture was stuffed into PVDC casing (VF612, Handtmann Co., Germany) with $\Phi 9 \mathrm{~mm}$ in diameter and steam heating (SMK 4000NS, Metatek Co., Ltd., Korea) of 55 min was made. After heating, it was cooled at $-20^{\circ} \mathrm{C}$, followed by slicing of $2.0 \mathrm{~mm}$ thick. Sliced samples were dried at 40,50 and $60^{\circ} \mathrm{C}$ for $5,6,7$ and $8 \mathrm{~h}$.

\section{Analysis items and method}

\section{Moisture content}

Moisture content (950.46B) was determined by weight loss after $12 \mathrm{~h}$ of drying at $105^{\circ} \mathrm{C}$ in a drying oven (SW90D, Sang Woo Scienctific Co., Korea) (AOAC, 2005).

\section{Water activity}

Ground dried meat samples were homogenized prior to measurement of water activity $\left(\mathrm{a}_{\mathrm{w}}\right)$. Approximately $2 \mathrm{~g}$ ground samples were put into a holding cup, and then determined by water activity meter (LabMaster-aw $\mathrm{CH}$ 8853 Lachen, Novasina, Switzerland).

\section{Shear force}

The shear force of samples was determined using a texture analyzer (TA-XT2 $i$, Stable Micro systems, England) at conditions of force $100 \mathrm{~g}$, rupture test distance $1.0 \mathrm{~mm} /$ $\mathrm{s}$, distance $30 \mathrm{~mm}$, pre test $3.0 \mathrm{~mm} / \mathrm{s}$, test speed $2.0 \mathrm{~mm} /$ $\mathrm{s}$, post test speed $10.0 \mathrm{~mm} / \mathrm{s}$, time $5.0 \mathrm{~s}$. The measurement was done with ten replicates of each sample.

\section{Sensory evaluation}

A trained thirty-member panel consisting of researchers of the Food Processing Research Center at Korea Food Research Institute in Korea was used to evaluate ground dried-pork meat products at the time. Each ground driedpork meat product was evaluated in terms of texture degree and overall acceptability. The ground dried-pork meat products were steam heating, cooled to $21^{\circ} \mathrm{C}$ for $3 \mathrm{~h}$, cut into quarters, and served to the panelists randomly. Each sample was coded with a randomly selected 3-digit number. Sensory evaluations were performed under fluorescent lighting. Panelists were instructed to cleanse their palates between samples using water. The texture degree (crispiness: 1=very soggy, 9=very crispy) and overall acceptability (preference: 1=very bad, 9=very good) of the cooked samples were evaluated using a 9-point descriptive scale. This analysis was conducted using the Hedonic test described by Choi et al. (2008).

\section{Statistical analysis}

All tests were done at least three times for each experimental condition and mean values were reported. The statistical analysis was performed by using Statistical Analysis System (version 8.0, SAS, USA) to calculate the average and standard deviation. When using Duncan's multiple range test method, the significance test $(\alpha=0.05)$ was carried out through multiple test. The correlation of water activity $\left(\mathrm{a}_{\mathrm{w}}\right)$ between moisture content and sensory evaluation was measured by using Pearson's correlation.

\section{Results and Discussion}

\section{Moisture content and water activity}

The results on the effect of binding agent on moisture 
Table 1. Moisture content (\%) of ground dried meat by binding agent types and drying condition

\begin{tabular}{cccccc}
\hline \hline Temp. $\left({ }^{\circ} \mathrm{C}\right)$ & Time $(\mathrm{h})$ & Glutinous rice flour & Potato starch & Soybean powder & Acorn powder \\
\hline & 5 & $15.07 \pm 0.07^{\mathrm{aB}}$ & $15.78 \pm 0.03^{\mathrm{aB}}$ & $17.08 \pm 1.60^{\mathrm{aAB}}$ & $18.36 \pm 0.35^{\mathrm{aA}}$ \\
40 & 6 & $13.44 \pm 0.25^{\mathrm{bC}}$ & $13.78 \pm 0.13^{\mathrm{bC}}$ & $15.47 \pm 0.03^{\mathrm{bB}}$ & $16.11 \pm 0.05^{\mathrm{bA}}$ \\
& 7 & $13.45 \pm 0.01^{\mathrm{bB}}$ & $10.42 \pm 0.31^{\mathrm{eC}}$ & $15.17 \pm 0.49^{\mathrm{cbB}}$ & $13.38 \pm 0.25^{\mathrm{dcA}}$ \\
& 8 & $11.95 \pm 0.47^{\mathrm{dcB}}$ & $8.68 \pm 0.38^{\mathrm{gC}}$ & $14.04 \pm 0.99^{\mathrm{cbA}}$ & $12.58 \pm 0.24^{\mathrm{dAB}}$ \\
\hline \multirow{3}{*}{50} & 5 & $14.59 \pm 0.47^{\mathrm{aB}}$ & $13.27 \pm 0.01^{\mathrm{bC}}$ & $13.87 \pm 0.25^{\mathrm{cBC}}$ & $16.80 \pm 0.21^{\mathrm{bA}}$ \\
& 6 & $12.38 \pm 0.12^{\mathrm{cB}}$ & $12.69 \pm 0.08^{\mathrm{cB}}$ & $11.78 \pm 0.35^{\mathrm{dC}}$ & $14.73 \pm 0.10^{\mathrm{cA}}$ \\
& 7 & $11.14 \pm 0.98^{\mathrm{deA}}$ & $9.22 \pm 0.05^{\mathrm{fB}}$ & $10.72 \pm 0.29^{\mathrm{edA}}$ & $10.91 \pm 0.02^{\mathrm{eA}}$ \\
& 8 & $10.42 \pm 0.31^{\mathrm{eA}}$ & $7.23 \pm 0.28^{\mathrm{hC}}$ & $8.46 \pm 0.07^{\mathrm{fB}}$ & $10.79 \pm 0.26^{\mathrm{eA}}$ \\
\hline \multirow{2}{*}{60} & 5 & $12.44 \pm 0.50^{\mathrm{cB}}$ & $11.80 \pm 0.13^{\mathrm{dB}}$ & $11.93 \pm 0.29^{\mathrm{dB}}$ & $13.43 \pm 0.23^{\mathrm{dcA}}$ \\
& 6 & $9.13 \pm 0.05^{\mathrm{f}}$ & $9.17 \pm 0.12^{\mathrm{f}}$ & $9.92 \pm 0.72^{\mathrm{e}}$ & $10.73 \pm 1.96^{\mathrm{e}}$ \\
& 7 & $8.48 \pm 0.26^{\mathrm{fA}}$ & $8.13 \pm 0.61^{\mathrm{gA}}$ & $8.46 \pm 0.07^{\mathrm{fA}}$ & $7.04 \pm 0.17^{\mathrm{fB}}$ \\
\hline
\end{tabular}

$\overline{\mathrm{A}-\mathrm{C}}$ Values with different superscripts in the same row with the same parameter differ significantly $(p<0.05)$.

${ }^{a-i}$ Values with different superscripts in the same column with the same parameter differ significantly $(p<0.05)$.

content of ground dried-pork meat product based on drying condition are shown in Table 1. After 5-hours of drying at $40^{\circ} \mathrm{C}$, the moisture content of ground dried-meat in the presence of glutinous rice flour, potato starch, soybean flour, and acorn flour additive was 15.07, 15.78, 17.08 , and $18.36 \%$, respectively. After 8 -hours of drying, the values were $11.95,8.68,14.04$, and $12.58 \%$ respectively, which decreased with increasing in drying time $(p<0.05)$. Also, moisture content decreased with increasing in drying temperature at the same drying time $(p<$ $0.05)$. With binding agents, the moisture content of acorn flour was the highest regardless of drying time, and the potato starch additive was the lowest $(p<0.05)$. And, as for potato starch, the difference of moisture contents after 5-hours of drying and 8-hours of drying was $7.1 \%$ at 40 ${ }^{\circ} \mathrm{C}$ which is the largest decrease of moisture. There was no difference in soybean flour at 6,7 and 8 hours of processing and the moisture decrease was the lowest with $3.04 \%$ at 5-hours and at 8-hours. According to Han et al. (2011), the semi-dried chicken jerky with konjac, egg albumin, and isolated soy protein had significantly higher moisture contents than control. Similar results were obtained by Kim et al. (2012) who found that semi-dried jerky with gelation and wheat fiber had higher moisture contents than control.

The result of water activity $\left(\mathrm{a}_{\mathrm{w}}\right)$ of ground dried-pork meat product by binding agents according to drying condition was shown in Table 2. $\mathrm{a}_{\mathrm{w}}$ ranged between 0.752 and 0.821 at $40^{\circ} \mathrm{C}$ for 5-hours of processing and between 0.650 and 0.680 at 8 -hours of processing, which decreased with longer drying time $(p<0.05)$. The water activity of sample was decreased in all binding agent groups and all drying temperatures. After 8 hours of drying at $60^{\circ} \mathrm{C}$, measurements for glutinous rice flour, potato starch, bean flour, and acorn flour were 0.519, 0.506, 0.509 , and 0.530 respectively. These results were significantly lower $(p<0.05)$. Likewise, there were no significant differences based on binding agent type. When it comes to binding agent type, regardless of drying conditions, adding bean flour resulted in the lowest and adding acorn flour showed the highest $(p<0.05)$. Accordingly, water activity tended to be low with higher drying temperature and longer drying time, and there was a difference in drying degree of binding agents. This was determined by differences of binding agents where non-meat ingredients prohibited the increase of binding capacity and texture (Allais, 2010). In general, $a_{w}$ ranges between 0.70 and 0.75 (Torres et al., 1994). The moisture contents and water activity of ground dried-meat product manufactured in this study was relatively low with values ranging between $6.45-18.36 \%$ and $0.506-0.821$, respectively. Accordingly, drying at $40^{\circ} \mathrm{C}$ for 8 -hours, $50^{\circ} \mathrm{C}$ for 7 hours, and $60^{\circ} \mathrm{C}$ for 6-hours, resulted in water activity lower than 0.668 , which prohibited microbial growth and increased storage capacity.

\section{Shear force}

The shear forces of ground dried-pork meat product in accordance with binding agent types and drying conditions are shown in Table 3. When dried for $5 \mathrm{~h}$ at $40^{\circ} \mathrm{C}$, the shear force of ground dried meat product varied depending on the binding agent added. The shear force in the presence of glutinous rice flour, potato starch, bean flour, acorn flour, was $2.88 \mathrm{~kg} / \mathrm{cm}^{3}, 4.31 \mathrm{~kg} / \mathrm{cm}^{3}, 3.48 \mathrm{~kg} /$ 
Table 2. Water activity $\left(a_{w}\right)$ of ground dried meat by binding agent types and drying condition

\begin{tabular}{cccccl}
\hline \hline Temp. $\left({ }^{\circ} \mathrm{C}\right)$ & Time $(\mathrm{h})$ & Glutinous rice flour & Potato starch & Soybean powder & Acorn powder \\
\hline & 5 & $0.752 \pm 0.004^{\mathrm{aC}}$ & $0.782 \pm 0.003^{\mathrm{aB}}$ & $0.801 \pm 0.013^{\mathrm{aAB}}$ & $0.821 \pm 0.006^{\mathrm{aA}}$ \\
40 & 6 & $0.719 \pm 0.008^{\mathrm{bC}}$ & $0.768 \pm 0.010^{\mathrm{baA}}$ & $0.732 \pm 0.004^{\mathrm{bBC}}$ & $0.749 \pm 0.009^{\mathrm{cdAB}}$ \\
& 7 & $0.690 \pm 0.010^{\mathrm{cB}}$ & $0.677 \pm 0.006^{\mathrm{dB}}$ & $0.724 \pm 0.008^{\mathrm{bA}}$ & $0.732 \pm 0.011^{\mathrm{dA}}$ \\
& 8 & $0.628 \pm 0.010^{\mathrm{eC}}$ & $0.650 \pm 0.004^{\mathrm{eB}}$ & $0.677 \pm 0.007^{\mathrm{dA}}$ & $0.680 \pm 0.004^{\mathrm{eA}}$ \\
\hline \multirow{3}{*}{50} & 5 & $0.679 \pm 0.002^{\mathrm{cB}}$ & $0.764 \pm 0.008^{\mathrm{bA}}$ & $0.697 \pm 0.006^{\mathrm{cB}}$ & $0.788 \pm 0.016^{\mathrm{bA}}$ \\
& 6 & $0.651 \pm 0.010^{\mathrm{dC}}$ & $0.708 \pm 0.004^{\mathrm{cB}}$ & $0.628 \pm 0.004^{\mathrm{eD}}$ & $0.773 \pm 0.011^{\mathrm{cbA}}$ \\
& 7 & $0.631 \pm 0.006^{\mathrm{eB}}$ & $0.643 \pm 0.006^{\mathrm{eB}}$ & $0.577 \pm 0.008^{\mathrm{fC}}$ & $0.668 \pm 0.008^{\mathrm{eA}}$ \\
& 8 & $0.610 \pm 0.003^{\mathrm{fB}}$ & $0.620 \pm 0.002^{\mathrm{fAB}}$ & $0.541 \pm 0.001^{\mathrm{gC}}$ & $0.626 \pm 0.006^{\mathrm{fA}}$ \\
\hline & 5 & $0.643 \pm 0.006^{\mathrm{edC}}$ & $0.687 \pm 0.014^{\mathrm{dB}}$ & $0.678 \pm 0.004^{\mathrm{dB}}$ & $0.733 \pm 0.016^{\mathrm{dA}}$ \\
& 6 & $0.600 \pm 0.002^{\mathrm{gBB}}$ & $0.577 \pm 0.007^{\mathrm{gB}}$ & $0.580 \pm 0.005^{\mathrm{fB}}$ & $0.664 \pm 0.021^{\mathrm{eA}}$ \\
& 7 & $0.593 \pm 0.080^{\mathrm{gA}}$ & $0.568 \pm 0.013^{\mathrm{gA}}$ & $0.516 \pm 0.008^{\mathrm{hB}}$ & $0.585 \pm 0.019^{\mathrm{gA}}$ \\
\hline
\end{tabular}

A-D Values with different superscripts in the same row with the same parameter differ significantly $(p<0.05)$.

${ }^{\text {a-h }}$ Values with different superscripts in the same column with the same parameter differ significantly $(p<0.05)$.

Table 3. Shear force of ground dried meat by binding agent types and drying condition (Unit: $\mathbf{~ k g} / \mathrm{cm}^{\mathbf{3}}$ )

\begin{tabular}{ccclll}
\hline \hline Temp. $\left({ }^{\circ} \mathrm{C}\right)$ & Time $(\mathrm{h})$ & Glutinous rice flour & Potato starch & Soybean powder & Acorn powder \\
\hline & 5 & $2.88 \pm 0.62^{\mathrm{gB}}$ & $4.31 \pm 0.49^{\mathrm{bA}}$ & $3.48 \pm 1.05^{\mathrm{fAB}}$ & $2.79 \pm 0.09^{\mathrm{hB}}$ \\
40 & 6 & $3.54 \pm 0.44^{\mathrm{fgC}}$ & $6.83 \pm 0.69^{\mathrm{aA}}$ & $3.92 \pm 0.95^{\mathrm{fC}}$ & $5.25 \pm 0.80^{\mathrm{cedB}}$ \\
& 7 & $4.35 \pm 0.64^{\mathrm{feB}}$ & $7.51 \pm 0.52^{\mathrm{aA}}$ & $4.55 \pm 0.65^{\mathrm{feB}}$ & $4.15 \pm 0.29^{\mathrm{fgB}}$ \\
& 8 & $6.65 \pm 0.82^{\mathrm{dc}}$ & $7.11 \pm 0.72^{\mathrm{a}}$ & $6.39 \pm 0.95^{\mathrm{bc}}$ & $6.45 \pm 0.88^{\mathrm{b}}$ \\
\hline \multirow{3}{*}{50} & 5 & $3.58 \pm 0.39^{\mathrm{fgAB}}$ & $4.24 \pm 0.43^{\mathrm{bA}}$ & $3.78 \pm 0.57^{\mathrm{fAB}}$ & $3.22 \pm 0.56^{\mathrm{hgB}}$ \\
& 6 & $3.24 \pm 0.30^{\mathrm{gC}}$ & $6.90 \pm 0.12^{\mathrm{aA}}$ & $3.81 \pm 0.90^{\mathrm{fC}}$ & $4.88 \pm 1.21^{\mathrm{feB}}$ \\
& 7 & $5.08 \pm 0.85^{\mathrm{eB}}$ & $6.99 \pm 0.77^{\mathrm{aA}}$ & $5.08 \pm 0.85^{\mathrm{deB}}$ & $5.08 \pm 0.85^{\mathrm{fedB}}$ \\
& 8 & $7.15 \pm 0.82^{\mathrm{bcAB}}$ & $7.54 \pm 0.58^{\mathrm{aA}}$ & $7.72 \pm 0.43^{\mathrm{aA}}$ & $6.24 \pm 0.89^{\mathrm{cbB}}$ \\
\hline \multirow{2}{*}{60} & 5 & $6.07 \pm 0.37^{\mathrm{dB}}$ & $7.53 \pm 0.59^{\mathrm{aA}}$ & $5.62 \pm 0.66^{\mathrm{dcBC}}$ & $4.94 \pm 0.73^{\mathrm{feC}}$ \\
& 6 & $6.10 \pm 0.52^{\mathrm{dB}}$ & $7.09 \pm 0.37^{\mathrm{aA}}$ & $6.10 \pm 0.52^{\mathrm{cB}}$ & $5.99 \pm 0.62^{\mathrm{cbdB}}$ \\
& 7 & $7.93 \pm 0.93^{\mathrm{ba}}$ & $6.68 \pm 0.86^{\mathrm{a}}$ & $6.10 \pm 0.52^{\mathrm{ba}}$ & $7.62 \pm 0.91^{\mathrm{a}}$ \\
& 8 & $8.45 \pm 0.84^{\mathrm{aA}}$ & $6.76 \pm 0.50^{\mathrm{aB}}$ & $7.65 \pm 0.45^{\mathrm{aA}}$ & $8.05 \pm 0.47^{\mathrm{aA}}$ \\
\hline
\end{tabular}

${ }^{\mathrm{A}-\mathrm{C}}$ Values with different superscripts in the same row with the same parameter differ significantly $(p<0.05)$.

${ }^{a-h}$ Values with different superscripts in the same column with the same parameter differ significantly $(p<0.05)$.

$\mathrm{cm}^{3}, 2.79 \mathrm{~kg} / \mathrm{cm}^{3}$, respectively. The shear force tended to increase when the drying time was longer. At 50 and $60^{\circ} \mathrm{C}$, as the drying time was extended, an increase in shear force was observed. When ground dried meat was dried for $5 \mathrm{~h}$ at $60^{\circ} \mathrm{C}$, the shear force ranged between $4.94-7.53 \mathrm{~kg} / \mathrm{cm}^{3}$, which was significantly higher than the conditions when meat was dried for $5 \mathrm{~h}$ at 40 and $50^{\circ} \mathrm{C}$, respectively. With reference to binding agent, the shear force of dried-meat product in the presence of added glutinous rice flour was the highest $\left(8.45 \mathrm{~kg} / \mathrm{cm}^{3}\right)$ when meat was dried for $8 \mathrm{~h}$ at $60^{\circ} \mathrm{C}$. Whilst comparing the results of moisture content and water activity, it is obvious that the shear forces tended to increase as moisture content became lower. These results were in agreement with Han et al. (2011) who reported that decreased shear force of semi-dried meat products were treatments as adding binding agent types. Kim et al. (2010) reported that the shear force of semi-dry jerky decreased with the addition of rice bran fiber, and shear force can be affected by water activity, moisture content, and cooking yield. In this study, the drying temperature and time were higher influence on the shear force than the adding binding agents.

\section{Sensory evaluation}

This study evaluated the degree of texture and overall acceptability through sensory evaluations. The result of sensory evaluations for ground dried-pork meat product on the basis of binding agents according to drying condition is shown in Table 4. As a result, regardless of binding agents, the degree of texture became higher when drying time was longer and it was significantly low at 5hours of drying $(p<0.05)$. Overall acceptability tended to increase with an increase in drying time. It was significantly low at 5 -hours of drying $(p<0.05)$ and there was no 
Table 4. Sensory properties of ground dried meat by binding agent types and drying condition

\begin{tabular}{|c|c|c|c|c|c|c|}
\hline Texture* & Temp. $\left({ }^{\circ} \mathrm{C}\right)$ & Time (h) & Glutinous rice flour & Potato starch & Soybean powder & Acorn powder \\
\hline \multirow{12}{*}{$\begin{array}{l}\text { Texture } \\
\text { degree }\end{array}$} & \multirow{4}{*}{40} & 5 & $4.00 \pm 0.82^{\mathrm{c}}$ & $4.98 \pm 0.58^{f}$ & $4.71 \pm 0.95^{\mathrm{d}}$ & $4.00 \pm 1.15^{\mathrm{c}}$ \\
\hline & & 6 & $6.14 \pm 0.90^{\mathrm{bB}}$ & $7.57 \pm 0.53^{\text {bdacA }}$ & $5.86 \pm 1.21^{\mathrm{bdcB}}$ & $6.86 \pm 1.07^{\mathrm{aAB}}$ \\
\hline & & 7 & $6.29 \pm 0.76^{\mathrm{bB}}$ & $7.29 \pm 0.49^{\mathrm{bdcA}}$ & $5.14 \pm 1.07^{\mathrm{dcC}}$ & $6.43 \pm 0.98^{\mathrm{aAB}}$ \\
\hline & & 8 & $6.43 \pm 1.13^{\mathrm{b}}$ & $6.71 \pm 1.11^{\mathrm{d}}$ & $6.14 \pm 1.07^{\mathrm{bac}}$ & $6.71 \pm 1.11^{\mathrm{a}}$ \\
\hline & \multirow{4}{*}{50} & 5 & $6.29 \pm 0.76^{\mathrm{bA}}$ & $5.98 \pm 1.00^{\mathrm{eAB}}$ & $6.57 \pm 1.13^{\text {bacA }}$ & $4.71 \pm 1.11^{\mathrm{cB}}$ \\
\hline & & 6 & $6.00 \pm 1.00^{\mathrm{bAB}}$ & $7.00 \pm 0.82^{\mathrm{dA}}$ & $5.29 \pm 1.25^{\mathrm{dcB}}$ & $6.43 \pm 0.79^{\mathrm{aA}}$ \\
\hline & & 7 & $6.43 \pm 0.53^{\mathrm{bAB}}$ & $8.00 \pm 0.82^{\text {bacA }}$ & $6.00 \pm 1.00^{\text {bdacB }}$ & $6.00 \pm 1.00^{\mathrm{baB}}$ \\
\hline & & 8 & $6.29 \pm 0.95^{\mathrm{bA}}$ & $7.14 \pm 0.69^{\mathrm{dcA}}$ & $6.57 \pm 1.13^{\text {bdacA }}$ & $5.00 \pm 1.15^{\mathrm{bcB}}$ \\
\hline & \multirow{4}{*}{60} & 5 & $7.71 \pm 0.95^{\mathrm{aA}}$ & $8.16 \pm 0.69^{\text {baA }}$ & $7.43 \pm 1.27^{\mathrm{aA}}$ & $6.14 \pm 0.69^{\mathrm{baB}}$ \\
\hline & & 6 & $7.57 \pm 1.13^{\mathrm{a}}$ & $7.29 \pm 0.95^{\mathrm{bdc}}$ & $7.29 \pm 1.38^{\mathrm{ba}}$ & $6.57 \pm 1.40^{\mathrm{a}}$ \\
\hline & & 7 & $7.71 \pm 0.95^{\mathrm{a}}$ & $7.71 \pm 0.95^{\mathrm{a}}$ & $7.43 \pm 1.40^{\mathrm{a}}$ & $7.29 \pm 0.76^{\mathrm{a}}$ \\
\hline & & 8 & $7.57 \pm 0.98^{\mathrm{aAB}}$ & $8.00 \pm 0.58^{\mathrm{bacA}}$ & $7.14 \pm 1.07^{\mathrm{baAB}}$ & $6.86 \pm 1.07^{\mathrm{aB}}$ \\
\hline \multirow{12}{*}{$\begin{array}{c}\text { Overall } \\
\text { acceptability }\end{array}$} & \multirow{4}{*}{40} & 5 & $5.43 \pm 0.79^{\mathrm{e}}$ & $5.51 \pm 0.96^{\mathrm{d}}$ & $4.86 \pm 0.90^{\mathrm{b}}$ & $5.43 \pm 0.53^{\mathrm{bc}}$ \\
\hline & & 6 & $6.57 \pm 0.98^{\text {bdac }}$ & $7.00 \pm 1.00^{\mathrm{bac}}$ & $6.71 \pm 0.49^{\mathrm{a}}$ & $6.71 \pm 0.76^{\mathrm{a}}$ \\
\hline & & 7 & $6.71 \pm 0.49^{\text {bdac } \mathrm{AB}}$ & $7.29 \pm 0.49^{\mathrm{baA}}$ & $6.43 \pm 0.53^{\mathrm{aB}}$ & $6.14 \pm 0.90^{\text {bacB }}$ \\
\hline & & 8 & $6.14 \pm 0.90^{\text {bdec }}$ & $6.71 \pm 0.95^{\text {bdac }}$ & $6.57 \pm 0.79^{\mathrm{a}}$ & $6.14 \pm 0.69^{\mathrm{bac}}$ \\
\hline & \multirow{4}{*}{50} & 5 & $6.00 \pm 1.00^{\text {bdec }}$ & $6.16 \pm 0.69^{\mathrm{bdc}}$ & $6.14 \pm 1.35^{\mathrm{a}}$ & $5.71 \pm 0.49^{\mathrm{bac}}$ \\
\hline & & 6 & $6.14 \pm 0.90^{\mathrm{dec}}$ & $6.71 \pm 1.11^{\mathrm{bdac}}$ & $6.00 \pm 0.82^{\text {ba }}$ & $5.86 \pm 0.90^{\mathrm{bac}}$ \\
\hline & & 7 & $7.57 \pm 0.79^{\mathrm{aAB}}$ & $7.00 \pm 1.15^{\mathrm{bacA}}$ & $6.00 \pm 0.82^{\mathrm{baB}}$ & $6.29 \pm 0.95^{\mathrm{baB}}$ \\
\hline & & 8 & $5.86 \pm 1.07^{\mathrm{de}}$ & $6.00 \pm 1.29^{\mathrm{dc}}$ & $6.14 \pm 1.35^{\mathrm{a}}$ & $5.00 \pm 1.15^{\mathrm{c}}$ \\
\hline & \multirow{4}{*}{60} & 5 & $6.86 \pm 0.90^{\text {bdacA }}$ & $7.82 \pm 0.69^{\mathrm{aA}}$ & $6.86 \pm 0.90^{\mathrm{aAB}}$ & $6.29 \pm 1.11^{\mathrm{baB}}$ \\
\hline & & 6 & $7.00 \pm 1.00^{\mathrm{bac}}$ & $7.43 \pm 0.79^{\mathrm{a}}$ & $6.00 \pm 1.29^{\text {ba }}$ & $5.86 \pm 1.07^{\mathrm{bac}}$ \\
\hline & & 7 & $6.86 \pm 0.69^{\mathrm{bdac}}$ & $6.86 \pm 0.69^{\mathrm{bac}}$ & $7.00 \pm 1.15^{\mathrm{a}}$ & $6.00 \pm 1.00^{\mathrm{bac}}$ \\
\hline & & 8 & $7.14 \pm 0.90^{\mathrm{baA}}$ & $7.71 \pm 0.49^{\mathrm{aA}}$ & $6.00 \pm 1.15^{\mathrm{baB}}$ & $6.00 \pm 1.15^{\text {bacB }}$ \\
\hline
\end{tabular}

*Degree (crispiness: 1=extremely soggy, $9=$ extremely crispy) and acceptability ( $1=$ very bad, $9=$ very good)

${ }^{\text {A-C }}$ Values with different superscripts in the same row with the same parameter differ significantly $(p<0.05)$.

${ }^{a-f}$ Values with different superscripts in the same column with the same parameter differ significantly $(p<0.05)$.

difference at 6,7 and 8-hours of drying. At condition of drying at $50^{\circ} \mathrm{C}$ for a longer time, the degree of texture in case of acorn flour was significantly low at 5 -hours and 8-hours of drying and there was no difference in degree of texture of in cases of glutinous rice flour, potato starch, and soybean flour additives $(p<0.05)$. Overall acceptability tended to be different as per the binding agents, when the drying time was longer. There was no significant difference in degree of texture and preferences for glutinous rice flour, potato starch, and soybean flour additive. In the case of acorn flour, the degree of texture was the highest at 7-hours of drying and it tended to decrease afterwards, as the texture hardened and led to low overall acceptability. No significant difference in degree of texture and overall acceptability for all binding agents was observed at drying condition of $60^{\circ} \mathrm{C}$, which is different from the results observed at 40 and $50^{\circ} \mathrm{C}$. It is judged to be due to the high drying temperature because of it was quickly dried. In the case of acorn flour, the sensory characteristics was significantly low 5-hours and 8-hours of drying and there was no significant difference at 6-hours and 7hours of drying according to the drying time $(p<0.05)$.
Accordingly, it was proven that degree of texture and overall acceptability increased when drying temperature was higher and the drying time was longer. Nevertheless, acorn flour had lower degree of texture at $50^{\circ} \mathrm{C}$ for 8 hours of drying. These findings agree with those reported by Han et al. (2011) who showed that semi-dried chicken jerky prepared with various ingredients have increased sensorial properties scores. Also, one of the main problems during drying was the increase in surface hardness due to low moisture content caused by crust formation (Quinton et al., 1997; Ruiz-Ramirez et al., 2005).

\section{Correlations between physicochemical and sensory characteristics}

Correlations between moisture content, water activity $\left(a_{w}\right)$, shear forces, and sensory characteristics were analyzed using a Pearson's correlation (Table 5). The correlation coefficient of moisture content and water activity was the highest with $0.904(p<0.01)$, in agreement with the report by Allen et al. (2007) saying that water activity and moisture content form a strong positive correlation. As a result, it is determined that water activity can be 
Table 5. Correlation coefficient between physicochemical and sensory properties of ground dried meat by binding agent types and drying condition

\begin{tabular}{cccccc}
\hline \hline & \multirow{2}{*}{ Moisture content } & \multirow{2}{*}{ Water activity } & \multirow{2}{*}{ Shear force } & \multicolumn{2}{c}{ Sensory properties } \\
\cline { 4 - 6 } & & & & Textural degree & Overall acceptability \\
\hline Moisture content & - & $0.904^{* *}$ & $-0.783^{* *}$ & $-0.607^{* *}$ & -0.029 \\
Water activity & - & $-0.679^{* *}$ & $-0.577^{* *}$ & -0.006 \\
& Shear force & & - & $0.680^{* *}$ & -0.015 \\
\hline $\begin{array}{c}\text { Sensory } \\
\text { properties }\end{array}$ & Textural degree & Overall acceptability & & & - \\
\hline$* p<0.01$ & & & & - \\
\hline
\end{tabular}

gauged by moisture content. The correlation coefficients of shear forces and moisture content, as well as shear forces and water activity $\left(\mathrm{a}_{\mathrm{w}}\right)$ were -0.783 and $-0.679(p<$ 0.01 ) respectively, which indicates highly negative correlations. As a result of correlation analysis tests for the sensory evaluation, texture type had negative correlations with moisture content and water activity (The correlation coefficients were -0.607 and $-0.57, p<0.01)$. However, it had a positive correlation with shear forces $(0.680, p<$ 0.01 ). There was no correlation with respect to overall acceptability, which is a sensory characteristic.

\section{Conclusion}

The purpose of this study was to investigate the influence of processing conditions (temperature and time) and binding agent types (glutinous rice flour, potato starch, bean flour, and acorn flour) on physicochemical and sensory characteristics of ground dried-pork meat product. As the drying temperature became higher and the drying time became longer, moisture content and water activity decreased but shear forces increased. However, there were differences depending on the binding agent types. The results showed there was a high correlation between moisture content, water activity, shear forces, and sensory evaluation (texture type) $(p<0.01)$. However, there was no correlation with respect to overall acceptability. Therefore, it is determined that various ground dried-pork meat product can be produced in accordance with diverse purposes by using different processing conditions and binding agent types. The use of binding agents enhanced the overall acceptability of the ground dried meat products, and the addition of potato was the most effective binding agent treatment in this study.

\section{Acknowledgements}

This research was supported High Value-added Food
Technology Development Program (2014-314068-3) by the Ministry of Agriculture, Food and Rural Affairs (Republic of Korea).

\section{References}

1. AOAC (2005) Official methods of analysis. $18^{\text {th }}$ ed., Association of Official Analytical Chemists, Washington, DC. 39, pp. 1-24.

2. Allais, I. (2010) Emulsification. In: F. Toldrá (Eds.), Handbook of meat processing. Iowa: Blackwell publishing. pp. 143-168.

3. Allen, K., Cornforth, D., Whittier, D., Vasavada, M., and Nummer, B. (2007) Evaluation on high humidity and wet marinade methods for pasteurization of jerky. J. Food Sci. 72, 351-355.

4. Banwart, G. J. (1979) Basic food microbiology. AVI Publishing Company Inc., Westport. CT. USA

5. Biscola, V., Todorov, S. D., Capuano, V. S. C., Abriouel, H., Gálvez, A., and Franco, B. D. G. M. (2013) Isolation and characterizaion of a nisin-like bacteriocin produced by lactococcus lactis strain isolated from charqui, a Brazillian fermented, salted and dried meat product. Meat Sci. 93, 607613.

6. Bone, D. (1973) Water activity in intermediate moisture foods. Food Technol. 27, 71-76

7. Carr, M. A., Miller, M. F., Daniel, D. R., Yarbrogh, C. E., Petrosky, J. D., and Thompson, L. D. (1997) Evaluation of the physical, chemical and sensory properties of jerky processed from emu, beef and turkey. J. Food Qual. 20, 419-425.

8. Chang, F. S., Huang, T. C., and Pearson, A. M. (1996) Control of the dehydration process on production of intermediate moisture meat products: a review. Adv. Food Nutr. Res. 29, 71-161.

9. Choi, Y. I. and An, K. Y. (1996) Effects of phosphate type and addition level on binding ability, microstructure and storage characteristics of restructured pork jerky. Korean $J$. Anim. Sci. Technol. 38, 159-170.

10. Choi, Y. S., Jeong, J. Y., Choi, J. H., Han, D. J., Kim, H. Y., Lee, M. A., Kim, H. W., Paik, H. D., and Kim, C. J. (2008) Effects of dietary fiber from rice bran on the quality characteristics of emulsion-type sausages. Korean J. Food Sci. An. 28, 14-20. 
11. Dzimba, F. E. J. M., Faria, J. A. F., and Walter, E. H. M. (2007) Testing the sensory acceptability of biltong formulated with different spices. Afri. J. Agri. Res. 2, 574-577.

12. Han, D. J., Choi, J. H., Choi, Y. S., Kim, H. Y., Kim, S. Y., Kim, H. W., Chung, H. K., and Kim, C. J. (2011) Effects of konjac, isolated soy protein, and egg albumin on quality properties of semi-dried chicken jerky. Korean J. Food Sci. An. 31, 183-190.

13. Han, D. J., Jeong, J. Y., Choi, J. H., Choi, Y. S., Kim, H. Y., Lee, M. A., Lee, E. S., Paik, H. D., and Kim, C. J. (2007) Effects of dying conditions on quality properties of pork jerky. Korean J. Food Sci. An. 27, 29-34.

14. Kim, H. Y., Kim, K. J., Lee, J. W., Kim, G. W., and Kim, C. J. (2012) Effects of chicken feet gelatin and wheat fiber levels on quality properties of semi-dried chicken jerky. Korean J. Food Sci. An. 32, 732-739.

15. Kim, Y. H., Choi, Y. S., Choi, J. H., Han, D. J., Kim, H. Y., Lee, M. A., Shim, S. Y., Paik, H. D., and Kim, C. J. (2010) Physicochemical properties and sensory characteristics of semi-dried pork jeky with rice bran fiber. Korean J. Food Sci. An. 30, 966-974.

16. Labuza, T. P., Cassil, S., and Sinsky, A. J. (1972) Stability of intermediate moisture foods. 2. Microbiology. J. Food Sci. 37, 160-162.

17. Lee, H. C. and Jin, K. B. (2004) Reduction of tumbling time and improvement of shear value for the manufacture of restructured hams using transglutaminase. Korean J. Food Sci. An. 24, 21-28.

18. Lee, S. J. and Park, G. S. (2004) The quality characteristics of beef jerky prepared with various spices. Korean J. Food Cookery Sci. 20, 489-497.

19. Lee, S. K., Kim, H. J., Kang, C. G., and Kim, S. T. (1997) Effects of temperature and time on physicochemical properties of Korean goat meat jerky during drying. Korean J. Food Sci. An. 17, 184-189.

20. Lee, S. W. and Kang, C. S. (2001) Effect of moisture content on quality changes of dried ostrich meat. J. Health Sci. Medical Technol. 27, 29-34.

21. Leistner, L. (1987) Shelf stable product and intermediate moisture foods based on meat. In: Water activity theory and application to Food, Rockland, I., and Beuchat, L. B. (eds.),
Marcel Dekker Inc., New York, pp 295-328.

22. Mgbemere, V. N., Akpapunam, M. A., and Igene, J. O. (2011) Effect of groundnut flour sbstitution on yield, quality and storage stability of kilishi Nigerian indigenous dried meat product. Afri. J. Food Agri. Nutr. Develop. 11, 4718-4738.

23. Munoz, I., Garcia-Gil, N., Arnau, J., and Gou, P. (2012) Rehydration kinetics at 5 and 15 of dry salted meat. J. Food Eng. 110, 465-471.

24. Park, C. J., Kim, M. L., and Park C. S. (2009) Effects of drying method and medicinal extract addition on the microstructure of beef jerky. Korean J. Food Preserv. 16, 875-883.

25. Park, J. H. and Lee. K. H. (2005) Quality characteristics of beef jerky made with beef meat of various places of origin. Korean J. Food Cookery Sci. 21, 528-535.

26. Pegg, R. B., Amarowicz, R., and Code, W. E., (2006) Nutritional characteristics of emu (Dromaius novaehollandiae) meat and its value added products. Food Chem. 97, 193-202.

27. Quinton, R. D., Cormforth, D. P., Hendricks, D. G., Brennand, C. P., and Su, Y. K. (1997) Acceptability and composition of some acidified meat and vegetable stick products. $J$. Food Sci. 62, 1250-1254.

28. Rahman, M. S., Salman, Z., Kadim, I. T., Mothershaw, A., Al-Tiziqi, M. H., Guizani, N., Mahgoub, O., and Ali, A. (2005) Microbial and physic-chemical characteristics of dried meat processed by different methods. Int. J. Food Eng. 1, 1-14.

29. Ruiz-Ramirez, J., Serra, X., Gou, P., and Arnau, J. (2005) Profiles of water content, water activity and texture in crusted dry-cured loin and in non-crusted dry-cured loins. Meat Sci. 69, 519-525.

30. Thomas, P., Yanis, C., Anne-sopie, P., Sunita, J. S., and Antoine, C. (2014) Physicochemical and microbiological characteristics of biltomg, a traditional salted dried meat of South Africa. Meat Sci. 96, 1313-1317.

31. Torres, E. A. F. S., Shimokomaki, M., Franco, B. D. G. M., Landgraf, M., Cavalho Junior, B. C. C., and Santos, J. C. (1994) Parameters determining the quality of charqui, an intermediate moisture meat products. Meat Sci. 38, 229-234.

32. Van Laak, R. L. J. M. (1994) Spoilage and preservation of muscle foods. In: Muscle foods. Kinsman. M., Kotula, A. W., and Breidenstein, B. C. (eds) Chapman \& Hall, Inc., NY. pp. 378-405. 